\title{
Becánics Adrienn¹: A konzuli védelem nyújtásának feltételei a magyar jogban
}

Debreceni Jogi Mühely, 2013. évi (X. évfolyam) 3. szám (2013. július) 172-180.

\section{Bevezető gondolatok}

Az állampolgárok külföldön történő védelmének egyik első dokumentumaként az 1849 márciusában elfogadott Paulskirchei Alkotmány tekinthető, melynek 189. §-a értelmében „külföldön minden német állampolgár a Birodalom védelme alatt áll.”2 Annak ellenére azonban, hogy a rendszerváltást megelőző időszakban számos volt szocialista ország is alkalmazott hasonló szabályozást, Magyarországon csak az 1987. évi 25. törvényerejü rendelet rögzítette először, hogy a „külföldön tartózkodó magyar állampolgárok jogainak és érdekeinek védelmét a Magyar Népköztársaság külképviseleti szervei látják el.”3 Ezt a törvényerejü rendeletet aztán hatályon kívül helyezte a külföldre utazásról és az útlevélről szóló 1989. évi XXVIII. törvény, mellyel lényegében egyidőben az Alkotmány 69. § (3) bekezdése kimondta, hogy „Minden magyar állampolgár jogosult arra, hogy törvényes külföldi tartózkodásának ideje alatt a Magyar Köztársaság védelmét élvezze.” Ezen a szabályon csak minimálisan, ám annál lényegesebben változtatott az új Alaptörvény, melynek XXVII. cikk (2) bekezdése értelmében „Minden magyar állampolgárnak joga van ahhoz, hogy külföldi tartózkodásának ideje alatt Magyarország védelmét élvezze.”

Az állampolgárok külföldi tevékenységükhöz kapcsolódóan joggal tarthatnak igényt arra, hogy az állampolgárságuk szerinti állam segítse, illetőleg szükség esetén védelemben részesítse őket. A „külföldi tevékenységükhöz kapcsolódó” fordulat ugyan látszólag pongyolának tünik, ám valójában mégsem az: ez nem csupán a külföldi tartózkodás során felmerülő eseteket jelenti, hanem a belföldön tartózkodó állampolgár külföldi ügyeivel (így például hagyatéki ügyek, külföldön ellene folyó eljárások, külföldön levő vagyontárgyával kapcsolatos kérdések) kapcsolatos kérdések is ide sorolhatóak.

Az államoknak tradicionálisan két eszköz áll rendelkezésükre ahhoz, hogy a segítségükre szoruló állampolgáraik számára védelmet biztosítsanak: az egyik a (magyar jog szerint alanyi 
jogon járó) konzuli védelem, míg a másik a szinte valamennyi állam joga alapján az állam diszkrecionális döntésén alapuló diplomáciai védelem.

A diplomáciai védelem szabályrendszerét a hazai szakirodalom a közelmúltban már részletesen elemezte ${ }^{4}$, ugyanakkor a konzuli védelem átfogó jellegű elemzésére tudomásom szerint nem került sor, bár természetesen sorra születtek és születnek résztanulmányok ebből a témakörből is. Az Eötvös Loránd Hallgatói Ösztöndíjpályázat keretében a 2012. nyarán a Külügyminisztérium Konzuli Főosztályán töltött szakmai gyakorlatom nyomán vállalkoztam ezért a konzuli védelem szabályainak részletes bemutatására. Fontosnak tartom kiemelni, hogy (szemben a diplomáciai védelem szabályaival) a konzuli védelem szabályai nem tekinthetőek statikusnak: azt többek között az Európai Unió jogalkotása is folyamatosan befolyásolja.

Jelen tanulmány keretei között a kutatásaim első lépéseként a konzuli védelem rendszertani és fogalmi kereteit, illetőleg a diplomáciai védelemtől történő elhatárolását kísérelem meg bemutatni.

\section{A diplomáciai és a konzuli védelem elhatárolása}

A köznyelvben igen gyakran összemosásra kerül a diplomáciai védelem és a konzuli védelem jogintézménye, jóllehet a kettő (bár több pontban hasonlóak egymáshoz) számos tekintetben eltér egymástól. Mindkettő elméleti alapja, hogy az állampolgár külföldi tartózkodása alatt az állama védelmére jogosult lehet, merthogy az állami személyi főhatalom (az állampolgárság tényéből fakadóan) rá is vonatkozik. ${ }^{5}$

A diplomáciai védelem lényegét tekintve nem más, mint valamely állam által az állampolgáraival vagy jogi személyeivel szemben ${ }^{6}$ egy másik állam által elkövetett, nemzetközi jogot sértő sérelemnek diplomáciai akció vagy más békés vitarendezési eszköz révén való kifogásolása a felelősség érvényesítése érdekében. ${ }^{7}$ 
A diplomáciai védelem célja tehát egy másik állam szervei által elkövetett jogsértés megszüntetése és jóvátétel követelése, azonban (miként azt a hágai Nemzetközi Bíróság is rögzítette) az állam a diplomáciai védelem nyújtásakor a saját jogait érvényesíti, még abban az esetben is, ha az állampolgár személyét éri a sérelem. ${ }^{8}$ Hasonló megállapítást tett korábban az Állandó Nemzetközi Bíróság is a Mavrommatis-ügyben: „Az állam, amely magáévá teszi valamely állampolgárának ügyét és annak érdekében diplomáciai lépést tesz vagy nemzetközi bírósági eljárást tesz folyamatba, tulajdonképpen saját jogát érvényesíti, azt a jogot, hogy biztosítsa saját polgárainak személye tekintetében a nemzetközi jog tiszteletbentartását."”

Jóllehet a diplomáciai védelemre az állampolgároknak és jogi személyeknek nincs alanyi joguk, lényegében semmi nem tiltja, hogy egy állam saját belső joga alapján azt alanyi jogon biztosítsa az állampolgárai és honosai számára. Ugyanakkor, miután ez nem az érintettek alanyi joga, hanem az állam által nyújtható védelem (még abban az esetben is, ha azt az állam minden állampolgára számára nyújtani köteles adott esetben), ezért nem tekinthető nemzetközi jogi szempontból elfogadhatónak a több dél-amerikai államban alkalmazott, ún. Calvo-záradékot tartalmazó szerződések megkötése, melyben a szerződést megkötő külföldi magánszemély vagy jogi személy elfogadta ügyében a belföldi bíróság joghatóságát és elöre lemondott arról a diplomáciai védelem lehetőségéről. ${ }^{10}$

A jelenleg hatályos nemzetközi jogi elöírások alapján egyértelmü, hogy a diplomáciai védelem nyújtására csak akkor van lehetőség, ha a sértett állampolgár (vagy jogi személy) a jogsérelem orvoslására rendelkezésére álló jogorvoslati lehetőségeket maradéktalanul kimerítette. Miként Hargitai József is megjegyzi, ez a szabály már csak azért is teljesen logikus, mert először a jogsértő államnak kell megadni a lehetőséget arra, hogy az esetleges hibákat korrigálja. Természetesen ha a jogsértés természetéből adódóan a belső jogorvoslati fórumokhoz fordulás lehetősége kizárt, a belső jogorvoslatok kimerítésének kötelezettsége sem terheli a sértettet. ${ }^{11}$

A konzuli védelem legalább négy alapvető dologban különbözik a diplomáciai védelemtől.

Egyrészt, szemben a diplomáciai védelemmel, a konzuli védelemnek nem feltétele, hogy az idegen állammal szemben történjen, adott esetben az is elképzelhető, hogy nincs is ellenérdekű fél, például egy elveszett útiokmány pótlása során. 
- Másfelől, a konzuli védelem lényegében a fogadó állam jogrendszere keretében, és nem pedig nemzetközi síkon zajlik.

- Harmadrészt, a konzuli védelemnek nem előfeltétele, hogy a fogadó állam szervei valamilyen jogsértést kövessenek el, sőt annak teljesen jogszerü eljárásai esetén is igénybe vehető.

- És végezetül, a konzuli védelem esetén nem előfeltétel a rendelkezésre álló belső jogorvoslatok kimerítése sem. ${ }^{12}$

Miként Hargitai József is megjegyzi, a konzulok érdekvédelmi feladatait az 1963. évi bécsi egyezmény szavatolja, mely érdekvédelmi tevékenység tartalmilag két dolgot foglal magában: a küldő állam honosainak (természetes és jogi személyeinek) védelmét, valamint a küldő állam honosai részére segítség és támogatás nyújtását. ${ }^{13}$

\section{A konzuli védelem fogalmi elemei az Alaptörvény szerint}

Elöljáróban fontosnak tartom annak rögzítését, hogy az Alaptörvény XXVII. cikk (2) bekezdése (csakúgy, mint korábban az Alkotmány 69. § (3) bekezdése) a konzuli védelem lehetőségét rögzíti. Ugyan egyes szakirodalmi források a magyar alkotmányos megfogalmazást diplomáciai védelemként is említik ${ }^{14}$, a magyar szakirodalom és gyakorlat szerint azonban itt „,csupán” konzuli védelemről van szó. ${ }^{15}$ Hargitai József ezt például azzal indokolja, hogy mivel a védelem kizárólag a (törvényes) külföldi tartózkodás idején áll fenn, ezért szükségképpen nem beszélhetünk diplomáciai védelemröl, hiszen az akkor is elképzelhető, ha egy belföldön tartózkodó állampolgár külföldi vagyonát éri sérelem. ${ }^{16}$

Ezt a megközelítést teljesen egyértelművé teszi az Alaptörvény indokolása, mely szerint az Alaptörvény ,,alapvetően a konzuli védelemre való jogot biztosítja és a nemzetközi jogi kötelezettségekkel összhangban értelmezendő."

Lényegesnek tartom annak rögzítését, hogy az Alaptörvény (és korábban az Alkotmány) csupán a konzuli védelem nyújtásának elvi kereteit határozza meg, azokat aztán egy külön törvény (a konzuli védelemről szóló 2001. évi XLVI. törvény) konkretizálja. 
Ez azt is jelenti, hogy adott esetben eltérhet egymástól a konzuli védelem nyújtásának alkotmányos és törvényi szintü kötelezettsége, mely eltérés azonban a gyakorlatban az állampolgárok számára aligha okoz érezhető különbségtételt.

A konzuli védelem nyújtásának az Alaptörvény megfogalmazásából következő módon két feltétele van: a konzuli védelem olyan állampolgárnak nyújtható (i), aki külföldön tartózkodik (ii). Az alábbiakban ezt a két feltételt elemzem.

\section{a, állampolgárság}

A magyar alkotmányos berendezkedés a konzuli védelem lehetőségét kizárólag a magyar állampolgárságú természetes személyek számára garantálja, a jogi személyek, illetőleg állampolgársággal nem rendelkező személyek számára (ideértve adott esetben akár a menekülteket, hontalanokat is) közvetlen módon nem. Ez természetesen nem azt jelenti, hogy a jogi személyek számára a konzuli védelem ne állna rendelkezésre, csupán azt, hogy számukra a védelem lehetőségét nem az Alaptörvény biztosítja: a konzuli védelemről szóló 2001. évi XLVI. törvény 20. § (1) bekezdése értelmében ugyanis „A jogi személy konzuli védelmére e törvény rendelkezései megfelelően irányadók."

Éliás Pál idézi Jaroslav Zourek csehszlovák jogásznak a konzuli kapcsolatok jogáról szóló 1963. évi bécsi egyezmény kodifikációs munkálatai során tett kijelentését, miszerint „A konzuli hatóságok csak azon személyek védelmében léphetnek fel, akik a küldő állam állampolgárai, s azok voltak az elszenvedett sérelem idején is." ${ }^{18}$ A konzuli védelem nyújtásának feltétele tehát a folyamatosság elvének érvényesülése, azaz a védelem nyújtásának alapját képező állampolgársági köteléknek mind a védelem alapjául szolgáló eseménysor idején, mind pedig a védelem nyújtásának időpontjában fenn kell állnia.

A konzuli védelem nyújtásának lehetősége, illetőleg kötelezettsége egyértelmủ szabályozásra kerül abban az esetben, ha az érintett magánszemély csak egy állam állampolgára. Más helyzet azonban akkor, ha az érintett magánszemély egyidejűleg két vagy több állam állampolgárságával is rendelkezik. 
A kettős vagy többes állampolgárok számára a konzuli védelem nyújtásának ésszerü korlátját jelenti a konzuli védelemről szóló 2001. évi XLVI. törvény 3. § (2) bekezdése, melynek értelmében „Más állampolgársággal is rendelkező magyar állampolgár a másik állampolgársága szerinti államban olyan mértékben jogosult a védelemre, amilyen mértékig azt a fogadó állam lehetővé teszi.” Éppen ezért a konzuli védelem eszköze (szemben adott esetben a diplomáciai védelemmel) nem tekinthető a határon túli magyarság hatékony jogvédelmét biztosító eszköznek a számukra kedvezményesen megszerezhető állampolgárság megadását követően sem.

Az állampolgársági elvet részben áttöri Magyarország Európai Uniós tagsága. Az Európai Unió Működéséről Szóló Szerződés 23. cikke értelmében ugyanis „Olyan harmadik ország területén, ahol az állampolgársága szerinti tagállam nem rendelkezik képviselettel, bármely uniós polgár jogosult bármely tagállam diplomáciai vagy konzuli hatóságainak védelmét igénybe venni ugyanolyan feltételekkel, mint az adott tagállam állampolgárai." Jóllehet számos szakirodalmi forrás ezt a védelmet diplomáciai védelemként (vagy diplomáciai és konzuli védelemként) említik ${ }^{19}$, meglátásom szerint egyértelmű, hogy a konkrét esetben kizárólag konzuli védelem lehetőségéről beszélhetünk. A Bizottság által kidolgozott, jelenleg is egyeztetés alatt álló irányelv-tervezet már helyesen konzuli védelemként nevesíti ezt a jogintézményt. $^{20}$

\section{b, (törvényes) külföldi tartózkodás}

Az Alkotmány 69. § (3) bekezdése a konzuli védelem lehetőségét csupán a törvényes külföldi tartózkodás esetére garantálta, ideértve a magánjellegü turistautat, szolgálati utat, külföldi kiküldetést vagy akár a néhány hónapos, tartós vagy állandó külhoni tartózkodást is. A korábban hatályos Alkotmány kommentárja megjegyzi, hogy a konzuli védelem kizárólag „,örvényes” külföldi tartózkodás eseteire történő fenntartása abszurd helyzetet eredményezne: eszerint például nem lehetett volna konzuli védelemben részesíteni azt az állampolgárt, akinek a tartós külföldi tartózkodása során lejárt az útlevelének érvényessége, és ekként külföldi tartózkodása már nem minősül jogszerünek. ${ }^{21}$

Meglátásom szerint ez az alkotmányos leszűkítés indokolatlan volt, azonban már eredeti formájában sem jelentette azt, hogy kizárólag a „törvényes” külföldi tartózkodás esetén járt 
volna a konzuli védelem lehetősége. Miként azt az állampolgársági feltétel vizsgálatánál is jeleztem, a 2001. évi XLVI. törvény 1. § (1) bekezdése értelmében „Magyarország a magyar állampolgár érdekeinek külföldön történő védelmét a konzuli szolgálat útján látja el.”, azaz a konzuli védelem nyújtásának törvényi feltétele nem követeli meg a törvényes külföldi tartózkodást, sőt még a külföldi tartózkodást sem, hiszen a védelem igénye adott esetben akár egy hagyatéki ügyben is felmerülhet. ${ }^{22}$ Ezzel egyezően fogalmaz a konzuli kapcsolatokról szóló 1963. évi bécsi egyezmény 5. cikke is, mely szerint a konzuli védelem jelenti a küldő állam honosainak képviseletét, ,amennyiben azok távollétük vagy bármely más ok miatt jogaikat és érdekeiket nem tudják időben megvédeni." ${ }^{23}$ Éliás Pál álláspontja szerint is teljesen egyértelmü, hogy az Alkotmány 69. § (3) bekezdése az állampolgárok jogainak belső védelme mellett, azon túlmenően, még a külföldi tartózkodásuk ideje alatt is biztosítja az állam védelmét. ${ }^{24}$

Az Alkotmány kommentárja arra utal, hogy a konzuli védelem lehetőségét kizárólag a törvényes külföldi tartózkodás eseteire fenntartó alkotmányi fordulat feltehetően a rendszerváltás előtti időszak egyik öröksége volt, hiszen annak idején a magyar jogrendszer különbséget tett a külföldön történő jogszerü és törvényellenes tartózkodás között, utóbbiak alatt értve különösen az emigránsokat. ${ }^{25}$

\section{Következtetések}

A diplomáciai és a konzuli védelem jogintézménye a nemzetközi jog klasszikus intézményei közé sorolható. Jóllehet egyes szakirodalmi források vitatták, hogy a magyar állampolgárok számára korábban az Alkotmány, illetőleg jelenleg az Alaptörvény diplomáciai vagy konzuli védelmet garantál-e, meglátásom szerint egyértelmű, hogy itt konzuli védelemről beszélhetünk. Az Alaptörvény a korábbi alkotmányszöveghez képest lényegében egyetlen szóban módosult: kihúzásra került belöle az a korlátozás, hogy csak a „törvényes” külföldi tartózkodás esetén illeti meg az állampolgárokat a konzuli védelem lehetősége.

Miként azonban a fentiekben bemutattam, valójában a kérdés megítélése nem ennyire egyszerü, hiszen adott esetben a belföldön (Magyarországon) tartózkodó állampolgár is 
jogosult lehet konzuli védelemre. Ezen túlmenően olyan esetek is elképzelhetőek, hogy a külföldön levő magyar állampolgár valamilyen okból kifolyólag mégsem részesülhet konzuli védelemben (például többes állampolgárságára tekintettel). A konzuli védelem nyújtásának új (ebben a tanulmányban érdemben nem elemzett) dimenzióját jelenti az Európai Unió keretében megvalósuló konzuli védelem lehetősége.

1 joghallgató, Debreceni Egyetem Állam- és Jogtudományi Kar. A kutatás a TÁMOP 4.2.4.A/2-11-1-2012-0001 azonosító számú „Nemzeti Kiválóság Program - Hazai hallgatói, illetve kutatói személyi támogatást biztosító rendszer kidolgozása és müködtetése konvergencia program" címü kiemelt projekt keretében zajlott. A projekt az Európai Unió támogatásával, az Európai Szociális Alap társfinanszírozásával valósul meg.

2 JAKAB András (szerk.), Az Alkotmány kommentárja II., Századvég, Budapest, 2009. 2461.

3 1987. évi 25. törvényerejű rendelet a külföldre utazásról és az útlevélről, lásd a 2. § (3) bekezdését.

4 Lásd különösen Schiffner Imola 2010-ben a Szegedi Tudományegyetem Állam- és Jogtudományi Karán készített, „A diplomáciai védelem a nemzetközi jogban” címü $\mathrm{PhD}$ értekezését.

${ }^{5}$ SCHIFFNER Imola, A diplomáciai és konzuli védelemhez való jog a magyar Alkotmányban. Kül-Világ 2011/1-2. szám 134.

${ }^{6}$ A diplomáciai kapcsolatokról szóló 1961. évi bécsi szerződés 3. cikk b, pontja csak a küldő állam állampolgárainak (az angol hiteles szöveg szerint: „nationals”) érdekvédelmét nevesíti, de ez értelemszerüen kiterjed a jogi személyekre is, amennyiben a küldő állam honosságával rendelkeznek.

${ }^{7}$ ILC Draft Articles on Diplomatic Protection (2006), 1. cikk

${ }^{8}$ ICJ, Nottebohm ügy (Liechtenstein vs. Guatemala), 1955. április 6-i ítélet, ICJ Reports 4.

${ }^{9}$ PCIJ, Mavrommatis ügy (Görögország vs. Egyesült Királyság), 1924. augusztus 30-i ítélet, idézi: HARASZTi György, A Nemzetközi Bíróság joggyakorlata, KJK, Budapest, 1958, 90.

${ }^{10}$ Bővebben lásd: SHEA, Donald, The Calvo Clause, University of Minnesota Press, 1955.

${ }^{11}$ HARGiTAi József, Nemzetközi jog a gyakorlatban, Magyar Közlöny Lap- és Könyvkiadó, Budapest, 2008, 203.

12 JAKAB i.m. 2465-2466.

${ }^{13}$ HARGITAI i.m. 207.

${ }^{14}$ Dugard, John R., First Report on Diplomatic Protection, International Law Commission (2000), 80. pont

${ }^{15}$ SCHIFFNER i.m. 141.

${ }^{16}$ HARGITAI József, Az állampolgárok védelmének nemzetközi jogi kérdései. In: BRAGYOVA András (szerk), Nemzetközi jog az új alkotmányban, KJK-MTA ÁJI, Budapest, 1997, 151.

${ }^{17} \mathrm{http} / / / \mathrm{www}$.parlament.hu/irom39/02627/02627.pdf Indokolás a XXV. cikkhez.

${ }^{18}$ ÉLIÁs Pál, A konzuli jog és a diplomáciai védelem alkotmányos kérdései. In: BRAGYOVA András (szerk.), Nemzetközi jog az új alkotmányban. KJK-MTA ÁJI, Budapest, 1997, 117.

${ }^{19}$ Lásd például a Bizottság Az Európai Unió polgárainak diplomáciai és konzuli védelme harmadik országokban címü Zöld Könyvét. Forrás: http://eurlex.europa.eu/LexUriServ/LexUriServ.do?uri=OJ:C:2007:030:0008:0013:HU:PDF (2013. június 4-i letöltés)

20 Javaslat: A Tanács irányelve, az uniós polgárok konzuli védelme külföldön. Forrás: http://eur-lex.europa.eu/LexUriServ/LexUriServ.do?uri=COM:2011:0881:FIN:HU:PDF (2013. június 4-i letöltés) 
${ }^{21}$ JAKAB i.m. 2469.

${ }^{22}$ TóTH Judit, Jog-e a konzuli védelemhez való jog? In: TóTH Károly (szerk.), In memoriam Nagy Károly egyetemi tanár. Acta Universitatis Szegediensis. Acta Juridica et Politica, Tom. LXI., Szeged, 2002, 351.

${ }^{23}$ 1963. évi bécsi egyezmény a konzuli kapcsolatokról (kihirdette: 1987. évi 13. törvényerejü rendelet), 5. cikk i, pont

${ }^{24}$ ÉLIÁS i.m. 119.

${ }^{25}$ JAKAB i.m. 2470. 